\title{
and Health (ICASSETH 2019) The Empowerment Strategy of Gapoktan Toward an Agribusiness Microfinance Institution in Rural Areas
}

\author{
Dedi Muhammad Siddiq* \\ Macquare University \\ Sydney, Australia \\ *dedi-muhammad.siddiq@hdr.mq.edu.au
}

\author{
Achmad Faqih \\ Faculty of Agriculture \\ Universitas Swadaya Gunung Jati Cirebon \\ afaqih024@gmail.com
}

\begin{abstract}
The basic strategy as the effort to strengthen the institution is through community empowerment, optimization of agribusiness potential, and capital funding. The institution is an important tool for running a program. This research intends to find out the work of the Association of Farmers Group (Gapoktan) PUAP Singa Pantura; and get the strategy to empower Gapoktan PUAP Singa Pantura to be an Agribusiness Microfinance Institution in Rural Areas. This research design used a descriptive qualitative method. The writers used a survey technique to collect the data. Based on purposive sampling, the writers selected Gapoktan Singa Pantura as the place of the research. The subject of the research is all member and board of Gapoktan PUAP Singa Pantura that manages the Direct Assistance for Rural Agribusiness Business Development (BLMPUAP). The total number of all members and board of Gapoktan is 48 people. The finding of this research showed that the level of performance and quality of Gapoktan Singa Pantura in Mertasinga Village, Gunung Jati, Cirebon is optimal. The priority strategy is to utilize the support of the government and the community to establish an Agribusiness Microfinance Institution through using either fund owned by Gapoktan or PUAP capital.
\end{abstract}

Keywords: strategy, empowerment, Gapoktan, microfinance institutions, agribusiness

\section{INTRODUCTION}

The development is a process or a series of activities that never stop to realize changes in people's lives to achieve improvements in the quality of life in environmental situations that always changes [1]. However, the development planning always has the same time to be continued by the next stages and it intends to improve the quality of life of the community and individuals in the environmental change that can happen in a certain time [2].

Agricultural development is a process intended to increase agricultural production and enhance the income and productivity of each farmer's business by adding capital, skills, and preservation of environmental resources [3]. The objectives of agricultural development are to increase the income and living standards of farmers and fishermen; to open the job vacancies; and to increase food security [4].

The experience of the monetary crisis in 1998 made all parties aware that the agricultural sector has a strategic role, large service as an engine, a shock absorber and a buffer for the national economy. Based on the real Gross Domestic Product (GDP), the agricultural sector has recovered before the crisis since 1999 or four years faster than the aggregate economy that recovered in 2003 [5]. The agricultural sector is also key to poverty alleviation, food security and employment providers [6].

The poverty in rural areas is the major national problem and is the main priority in developing social welfare [7]. Therefore, the national economic development based on agriculture and rural areas will impact reducing the poor population [8].

The wide poverty among the farmers is caused by the debt in either original debt or ijon (buy rice from a farmer by paying for in long before the harvest). So the most difficult problem in agriculture is financing [9]. Farmers cannot increase their production because of lack of funds. They need cheap credit from community banks and other financial institutions [10]. The farmers who have a debt through ijon system are caused by the absence of alternative credit for farmers [11,12]. For this reason, one of the ways to solve this problem is through PUAP program [13].

Since 2008, the Department of Agriculture has implemented a breakthrough program in agricultural development named Rural Agribusiness Development (PUAP). This program is closely related to the National Program for Independent Community Empowerment (PNPM-Mandiri) which is under the coordination of the Office of the Coordinating Minister for People Welfare. The program is expected to reduce poverty and unemployment in rural areas by growing and developing agribusiness activities in rural areas under regional potential. PUAP is facilitation of venture capital assistance for member farmers, both owner farmers, sharecroppers, farm labourers and farm households, coordinated by the Group of Farmers (Gapoktan) [14].

One indicator to assess Gapoktan as agribusiness microfinance institutions is by looking at the performance of Gapoktan. Performance and Achievement Assessment of Gapoktan covers organizational aspects, aspects of PUAP fund distribution, aspects of PUAP program fund utilization, aspects of PUAP funding repayment [15].

The basic strategy to strengthen the institution is through community empowerment, optimization of agribusiness potential, and facilitation of venture capital [16]. During this time, institutions have been used as an important tool for 
running a program. However, the use of institutional stabilization strategies often faces inaccuracies and errors.

Gapoktan Singa Pantura is Gapoktan that receives Independent Direct Assistance (BLM) -PUAP by the Government of Cirebon as the implementer of the PUAP Program for the 2015-2016 periods, located in Mertasinga Village, Gunung Jati District, Gunung Jati, Cirebon Regency. The Micro Finance Institute has not been made since PUAP Program activities are implemented in 2014 by considering all efforts have been made for this program, starting from the planning, program implementation and the allocated funds.

The aim of this research is to find out the performance of Gapoktan PUAP Singa Pantura and get the strategies to empower Gapoktan PUAP Singa Pantura to be an Agribusiness Microfinance Institution in Rural Areas.

\section{RESEARCH METHOD}

This research was conducted in Mertasinga Village, Gunung Jati District, Cirebon Regency. The location of the research is selected purposively. Purposive is a technique to determine a sample with certain considerations [17]. This research was conducted from May to August 2018.

This research used a descriptive quantitative method. The writers used a survey to collect the data [18]. This method is used to find out the fact with correct interpretation and to seek a systematic picture [17]. Gapoktan Singa Pantura is selected as the location of the research purposively. There are 48 people as the subject of this research. They are all members and boards of Gapoktan Singa Pantura that manage the Direct Assistance for Rural Agribusiness Business Development.

The analytical methods used are Importance Performance Analysis (IPA), Internal Factor Evaluation (EFE), External Factor Evaluation (EFE), IE Analysis (Internal-External), SWOT Analysis (Strengths-Weaknesses-OpportunitiesThreats), and Quantitative Strategies Planning Matrix (QSPM) Analysis

\section{RESULTS AND DISCUSSION}

\section{A. Performance Analysis of Gapoktan Singa Pantura}

To determine the satisfaction of members of Gapoktan performance, it can be known through calculating the
Importance Analysis Performance (IPA). After the calculation, the satisfaction of the members is known at quadrant $B$ on the Cartesian diagram (figure 1).

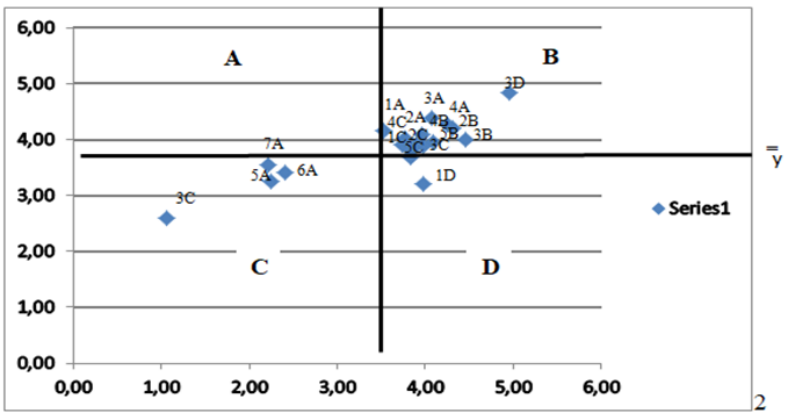

Fig. 1. The Cartesian diagram of the assessment between the satisfaction and the performance of Gapoktan Singa Pantura.

Interpreting the previous diagram can be explained: Quadrant B is the factors or attributes that influence the satisfaction of Gapoktan Singa Pantura members. This quadrant needs to be maintained because, the implementation is in line with the interests and expectations of members so it can satisfy members. This is under the opinion of Supranto, satisfaction is the level of one's feelings after comparing performance with expectations and results [19]. If the performance exceeds expectations, the customer will be very satisfied.

The factors in quadrant B are: a). Gapoktan has an organizational structure, b) Gapoktan describes the main tasks, c) Gapoktan organizes meetings/management meetings, d). the role of extension counsellor, e) the involvement of Gapoktan members in making RUB, $f$ ) the availability of PUAP funds, $g$ ) the ease of PUAP recipient requirements, h) PUAP Distribution Socialization, i) the selection of prospective PUAP recipients, j) as savings and loan unit/LKMA, k) the understanding of the suitability of the funds received with the needs of farming, 1) the understanding the deposits for LKMA, $\mathrm{m})$ the fulfilment of initial funding for LKMA establishment, n) PUAP revolves around other groups, o) the understanding of the total revolving fund.

\section{B. The Empowerment of Gapoktan Singa Pantura}

Matrix Analysis of IFE (Internal Factor Evaluation). The result of IFE matrix analysis can be seen in Table 1.

TABLE I. IFE (INTERNAL FACTOR EVAluAtion) MATRIX OF GAPOKTAN Singa PANTURA

\begin{tabular}{|c|c|c|c|c|}
\hline No & Internal Strategic Factors & Weight & Rating & Weighed Value \\
\hline$A$ & $\begin{array}{ll}\text { Strengths } \\
\end{array}$ & & & \\
\hline 1 & Intensive communication among gapoktan (A) & 0,06 & 3 & 0,20 \\
\hline 2 & Optimal financial management (B) & 0,07 & 3 & 0,24 \\
\hline 3 & The adequate skills of Gapoktan members $(\mathrm{C})$ & 0,07 & 3 & 0,23 \\
\hline 4 & Institution of Gapoktan is legalized by the government (D) & 0,07 & 4 & 0,24 \\
\hline 5 & The wide potential in business development in Gapoktan (E) & 0,07 & 4 & 0,27 \\
\hline 6 & Gapoktan has a wide network $(\mathrm{F})$ & 0,06 & 4 & 0,21 \\
\hline 7 & Initial capital meets the formation of LKMA (15\% from PUAP funds) $(\mathrm{G})$ & 0,08 & 4 & $\mathbf{0 , 3 0}$ \\
\hline 8 & There are adequate human resources to establish LKMA $(\mathrm{H})$ & 0,07 & 4 & 0,26 \\
\hline 9 & Gapoktan has complete administrative records (I) & 0,07 & 3 & 0,22 \\
\hline 10 & Gapoktan administrators manage their own PUAP funds $(\mathrm{J})$ & 0,06 & 2 & 0,10 \\
\hline \multicolumn{2}{|r|}{ P } & 0,68 & & 2,27 \\
\hline
\end{tabular}


Table I. Cont.

\begin{tabular}{|c|c|c|c|c|}
\hline No & Internal Strategic Factors & Weight & Rating & Weighed Value \\
\hline$B$ & \begin{tabular}{|c|} 
Weaknesses \\
\end{tabular} & & & \\
\hline 1 & The low level of Gapoktan members in Education (K) & 0,07 & 1 & $\mathbf{0 , 0 8}$ \\
\hline 2 & Savings and loan units have not been established/ LKMA (L) & 0,06 & 1 & 0,09 \\
\hline 3 & Gapoktan does not have its own office $(\mathrm{M})$ & 0,06 & 2 & 0,09 \\
\hline 4 & Limitation of land ownership of Gapoktan members (N) & 0,07 & 1 & 0,09 \\
\hline 5 & The technology used is not optimal $(\mathrm{O})$ & 0,07 & 1 & 0,08 \\
\hline \multicolumn{2}{|c|}{ Total } & $\mathbf{0 , 3 2}$ & & $\mathbf{0 , 4 2}$ \\
\hline \multicolumn{2}{|c|}{ The difference of weighed value in strengths and weaknesses } & & & 1,84 \\
\hline \multicolumn{2}{|c|}{ Total } & $\mathbf{1 , 0 0}$ & & 2,69 \\
\hline
\end{tabular}

Based on the results of the IFE matrix calculation, the strategic factor which is the biggest and most influential force for Gapoktan Singa Pantura in determining this empowerment model is the initial capital to establish LKMA (15\% of PUAP funds) $(G)$ with a weighed value of 0.30 . The final cumulative value for weakness factors is the low level of Gapoktan members in education $(\mathrm{K})$ with a weighed value of 0.08 , and the technology used is not optimal $(\mathrm{O})$ with a weighed value of 0.08 .

The advantages of the company that don't have distinctive competencies must be integrated into the culture of the organization in such a way that other companies are difficult to imitate [20].

\section{Matrix Analysis of EFE (External Factor Evaluation)}

Based on the results of the EFE matrix calculation (Table 2 ), the strategic factor which is the biggest and most influential opportunity for Gapoktan Singa Pantura in determining this empowerment model is the support of both the government and the local community to establish LKMA (B) with a score of 0.47. The final cumulative of the largest score for the threat factor is that farming depends on climate (E) with a weighed value of 0.38 .

The plan of strategy must analyse the external environment to find out the various opportunities and threats before it is implemented because it might affect the company [20].

The results of the external analysis are used to find out the opportunities and threats that exist and how well the strategy has been carried out so far. There are five steps in developing an EFE matrix [20].

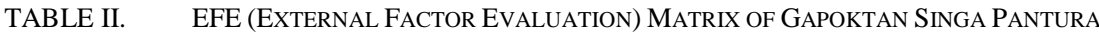

\begin{tabular}{|l|l|l|l|l|}
\hline No & \multicolumn{1}{|c|}{ External Strategic Factors } & Weight & Rating & Weighed Value \\
\hline $\boldsymbol{A}$ & \multicolumn{1}{|c|}{ Opportunities } & & \\
\hline 1 & Financial Support from Central and Regional Government (A) & 0,14 & 3 & 0,46 \\
\hline 2 & Support from Government and local communities to establish LKMA (B) & 0,14 & 4 & 0,47 \\
\hline 3 & Intensive Guidance From Officers to Gapoktan Members (C) & 0,13 & 3 & 0,39 \\
\hline 4 & CSR Support from Private Companies (D) & 0,09 & 3 & 0,25 \\
\hline Total & \multicolumn{1}{|c|}{ Threats } & & \\
\hline $\boldsymbol{B}$ & Farming Depends on Climate (E) & 0,13 & 3 & \\
\hline 1 & Limited access and production facilities (F) & 0,12 & 3 & 0,38 \\
\hline 2 & Ease of loans From Creditor and Ijon (G) & 0,06 & 2 & 0,32 \\
\hline 3 & The policy of HPP doesn't support the farmers (H) & 0,09 & 2 & 0,11 \\
\hline 4 & It is hard to access Government Credit Schemes (I) & 0,10 & 3 & 0,14 \\
\hline 5 & 0,50 & & 0,30 \\
\hline Total & & & 1,25 \\
\hline The difference of weighed value in opportunities and threats & 1,00 & & 0,32 \\
\hline Total & & 2,83 \\
\hline
\end{tabular}

\section{Matrix Analysis of Internal-External}

the $\mathrm{X}$ axis and the total value of EFE with the weight of 2.83 is

The IE matrix is based on two key dimensions: The total at the medium point on the $\mathrm{Y}$ axis. value of IFE with the weight of 2.69 is at the medium point on

TABLE III. I-E MATRIX

\begin{tabular}{|c|c|c|c|c|c|}
\hline \multirow{4}{*}{ 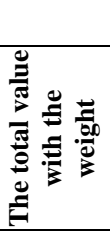 } & \multirow{2}{*}{ High } & & 3 & 2 & 1 \\
\hline & & 3 & 1. growing and developing & 2. growing and developing & 3. enduring and maintaining \\
\hline & Medium & 2 & 4. Growing and developing & $\begin{array}{lll}5 . \quad \text { enduring and } \\
\text { maintaining }\end{array}$ & 6. harvesting and releasing \\
\hline & Weak & 1 & 7. enduring and maintaining & 8. harvesting and releasing & 9. harvesting and releasing \\
\hline & & & Strong & average & Weak \\
\hline & & & The total value with the weig & & \\
\hline
\end{tabular}


Gapoktan stands in cell 5 (moderate attractive industry), the strategy used is more defensive, which is to avoid losing sales and losing profits. Organizations in this cell can expand markets, facilities and technology through internal and external development through acquisitions.

TABLE IV. MATRIX ANALYSIS OF SWOT

\begin{tabular}{|l|l|}
\hline \multicolumn{1}{|c|}{ SO } & \multicolumn{1}{|c|}{ WO } \\
\hline $\begin{array}{l}\text { Utilizing support from both the } \\
\text { government and the community } \\
\text { in establishing LKMA through } \\
\text { the use of both self-help fund } \\
\text { owned by Gapoktan and PUAP } \\
\text { fund }\end{array}$ & $\begin{array}{l}\text { Utilizing support from both the } \\
\text { government and the community to } \\
\text { provide training for members with } \\
\text { low education especially when } \\
\text { getting new technology. }\end{array}$ \\
\hline $\begin{array}{l}\text { Using self-help fund and PUAP } \\
\text { fund that have been collected in } \\
\text { Gapoktan to increase farming } \\
\text { capital needs in order to } \\
\text { anticipate seasonal changes. }\end{array}$ & $\begin{array}{l}\text { Increasing the knowledge of } \\
\text { Gapoktan members in utilizing } \\
\text { technology to anticipate changes } \\
\text { in weather. }\end{array}$ \\
\hline \multicolumn{2}{|c|}{}
\end{tabular}

The matching phase (SWOT matrix) aims to produce an alternative strategy. The followings result from the SWOT Matrix analysis. Based on the results of the SWOT Matrix analysis, there are four alternative strategies:

1) $\mathrm{S}-\mathrm{O}$ (Strengths-Opportunities) strategy: Utilizing support from both the government and the community in establishing LKMA through the use of both self-help fund owned by Gapoktan and PUAP fund

2) $W-O$ (Weakness-Opportunities) strategy: Utilizing support from both the government and the community to provide training for members with low education especially when getting new technology.

3) $S$-T (Strengths-Threats) strategy: Using self-help fund and PUAP fund that have been collected in Gapoktan to increase farming capital needs to anticipate seasonal changes.

4) $W-T$ (Weakness-Threats) strategy: Increasing the knowledge of Gapoktan members in utilizing technology to anticipate changes in weather.

\section{E. Decision Stage}

Based on the formulation of the priority matrix in the alternative strategies with the main factors, the priority scale of the main strategy is to run an alternative SO strategy in utilizing support from both the government and the community in establishing LKMA through the use of both self-help fund owned by Gapoktan and PUAP fund with the weight of 3.7.

The strengths of Gapoktan are: intensive communication among gapoktan, optimal financial management, the adequate skills of Gapoktan members, institution of Gapoktan is legalized by the government, the wide potential in business development in Gapoktan, Gapoktan has a wide network, initial capital meets the formation of LKMA (15\% from PUAP funds), there are adequate human resources to establish LKMA, Gapoktan has complete administrative records, and Gapoktan administrators manage their own PUAP funds. These strong factors are group assets that must be used optimally to get other opportunities.
Any alternative set of strategies can be included in the Quantitative Strategic Planning Matrix (QSPM), and many strategies can be included in each set, but only the strategies in a particular set are evaluated relative to one another [21].

\section{CONCLUSION}

The performance of Gapoktan Singa Pantura stands in quadrant B, which shows the factors or attributes that affect the satisfaction of members of Gapoktan Singa Pantura. This quadrant needs to be maintained because; in general, the level of implementation is under the interests and expectations of members so that it can satisfy members. The factors in quadrant B are a) Gapoktan has an organizational structure, b) Gapoktan describes the main tasks, c) Gapoktan organizes meetings/management meetings, d). the role of extension counsellor, e) the involvement of Gapoktan members in making RUB, $f$ ) the availability of PUAP funds, g) the ease of PUAP recipient requirements, h) PUAP Distribution Socialization, i) the selection of prospective PUAP recipients, j) as savings and loan unit/LKMA, k) the understanding of the suitability of the funds received with the needs of farming, 1) the understanding the types of deposits for LKMA, m) the fulfilment of initial funding for LKMA establishment, n) PUAP revolves around other groups, o) the understanding of the total revolving fund.

Based on the results of the analysis of internal and external factors in the strategy planning matrix, the empowerment of the Singa Pantura Gapoktan empowerment model towards the formation of LKMA uses the power that Gapoktan already has to get the opportunity. The QSPM results are obtained under the priority of the strategy like utilizing support from both the government and the community in establishing LKMA through the use of both self-help fund owned by Gapoktan and PUAP fund with the weight of 3.7 .

\section{REFERENCES}

[1] P.S.N. Lee, "Mass communication and national development in China: Media roles reconsidered," Journal of Communication, vol. 44, no. 3, pp. 22-37, 1994

[2] A. Faqih, "Hubungan Kemampuan Kelompok Dengan Dinamika Kelompok Wanita Tani," Agrijati Jurnal Ilmiah Ilmu-ilmu Pertanian, vol. 31, no. 1, pp. 27-38, 2017

[3] R.F. Arnove, Educational Television: A Policy Critique and Guide for Developing Countries. New York: Praeger, 1976.

[4] M. Mardikanto, Pemberdayaan Masyarakat Dalam Perspektif Kebijakan Publik. Bandung: Alfabeta, 2012.

[5] E. Abdurahman, PDB Sektor Pertanian. Buletin PDB Sektor Pertanian Jakarta Volume III No. 1 2004. Jakarta, 2004.

[6] P. Mefalopulos and C. Kamlongera, Communication for Development, Harare and Food and Agriculture Organization of the United Nations, Second Edition. Rome, 2004.

[7] R. Fernández and H. Dilla, Cultura política y participación popular en Cuba,' Cuadernos de Nuestra América, vol. III, 1990.

[8] R. Hornik, Development Communication: Information, Agriculture \& Nutrition in the Third World. New York: Longman, 1988.

[9] E. Mahan, "Mass-Media and Society In 20th-Century Mexico," Journal of the West, vol. 27, no. 4, pp. 41-49, 1988.

[10] E. Rogers, Inquiry in Development Communication" in Asante, M. and Gudykunst, W. (eds.) Handbook of International and Intercultura Communication Newbury Park, California, 1989. 
[11] L. Leogrande, Modes of Political Participation in Revolutionary Cuba. Pennsylvania: University of Pennsylvania Press, 1977.

[12] M. Azicri, 'The Institutionalization of the Cuban State," Journal of Interamerican Studies and World Affairs, vol. 22, no. 3, 1980.

[13] M. Mubyarto, Ekonomi dan Keadilan Sosial. Yogyakarta: Aditya Media, 1995.

[14] Departemen Pertanian, Pedoman Umum Pengembangan Usaha Agribisnis Pedesaan (PUAP). Jakarta: Tabloid Sinar Tani Bekerja Sama Dengan Badan Pengembangan SDM Pertanian, 2008.

[15] Kementrian Pertanian, Kementrian Perbanyak Program Pemberdayaan Petani. [Online]. Retrieved from: http://www.deptan.go.id, 2010.
[16] C. Tilly, "Models and Realities of Popular Collective Action," Social Research, vol. 52, no. 4, pp. 717-747, 1985.

[17] S. Sugiyono, Metode Penelitian Kuantitatif, Kualitatif dan R\&D. Bandung: CV. Alfabeta, 2009.

[18] M. Singarimbun and S. Effendi, Metode Penelitian Sosial. Jakarta: LP3ES, 1995.

[19] J. Supranto, Pengukuran Tingkat Kepuasan Pelanggan Untuk Menaikkan Pangsa Pasar. Jakarta: PT Rineka Cipta, 2011.

[20] F. Rengkuti, Analisis SWOT Teknik Membedah Kasus Bisnis. Jakarta: PT. Gramedia Pustaka Utama, 2009.

[21] F.R. David, Manajemen Strategis Konsep, terjemahan. Jakarta: PT. Salemba Empat, 2011. 